\title{
シンポジウム $2:$ 気管・食道領域のレーザー癌治療
}

\section{B 。喉頭癌の $\mathrm{CO}_{2}$ レーザー治療}

\author{
田部 哲也, 井上 鐵三, 小倉 雅 実 \\ 北原哲, 田中英一, 西沢伸志 \\ 坂田淳一
}

\section{Symposium 2 : Cancer Treatment by Laser in the Tracheo-esophageal Region B. $\mathrm{CO}_{2}$ Laser Management of Laryngeal Cancer}

\author{
Tetsuya Tanabe, M.D., Tetsuzo Inouye, M.D., Masami Ogura, Ph.D., \\ Satoshi Kitahara, M.D., Eiichi Tanaka, M.D., \\ Shinji Nishizawa, M.D., and Junichi Sakata, M.D. \\ Department of Otolaryngology, National Defense Medical College, Saitama
}

\begin{abstract}
$\mathrm{CO}_{2}$ laser was applied via laryngomicrosurgery to 36 laryngeal cancer (glottis) patients from April, 1982 to March, 1988. Seven cases were not cured by laser and underwent laryngectomy. The patients were followed up for 9 to 80 months (mean 38 months). Thirty-five cases $(97 \%)$ are survived without an evidence of recurrence. From this follow-up study we concluded as follows: 1) T1a can be treated by laser alone. 2) T1b can be treated by laser alone or by a combination of laser and radiation, and 3) a careful selection of cases for laser use is required in $\mathrm{T} 2$.
\end{abstract}

Key words : laryngeal cancer, $\mathrm{CO}_{2}$ laser

\section{はじめに}

喉頭癌治療に $\mathrm{CO}_{2}$ レーザーを用いるメリッ トとして, 出血が少ない, 腫瘍細胞の播種が少 ない, 術後の疼痛が極めて軽微, 術創の浮腫, 肉芽形成, 線維化が少ない, 喉頭顕微手術下に 遠隔照射が可能といつたものが挙げられる1)。 これらの利点を利用して, 従来 $\mathrm{T} 1$ 症例に行わ れていた放射線治療と変わるべく, また T 2 症 例を stage downさせ放射線治療との併用で治 瘺すべく, 本邦でも約 10 年前から喉頭癌に対し て $\mathrm{CO}_{2}$ レーザーが用いられてきている。

防衛医科大学校耳鼻咽喉科

別刷請求 : $=359$ 埼玉県所沢市並木3-2 防衛医科大学校耳鼻咽喉科 田部哲也
そこでレーザーと放射線とを比較してみる と, 治療期間では放射線が 6 ～週かかるのに 対してレーザーでは 1 日ですみ，また放射線で は一時的にせよ咽喉頭炎に悩まされたり将来の 発癌といった副作用がみられる。このように優 れた点を持つレーザー治療が適応を獲得するた めに注，放射線と同等あるいはそれ以上の治癒 率を上げ，治療後の音声も大きな障害がないと いうことが必要となる。

私どもは約 7 年前から喉頭癌に対して $\mathrm{CO}_{2}$ レーザー治療を行っており2), 今回主としてそ の治療成績について検討を加えたので報告す る。 
表 1 レーザー治療症例の T. N. M. 分類

\begin{tabular}{lrllll} 
T1a & 17. & N0 & 36. & M0 & 36. \\
T1b & 14. & & & & \\
T2 & 5. & & & & \\
\hline
\end{tabular}

\section{対象および方法}

今回検討を行った対象は，昭和57年 4 月から 昭和63年 3 月の間に治療を行った声門部癌新鮮 例36例である。T.N.M.分類を表 1 に示す。

組織型は全例扁平上皮癌で，低分化型 1 例， 中分化型 8 例, 高分化型15例, 分類不能12例で あった。

年齢は平均61歳（38歳から79歳）で，性別は 男性34例，女性 2 例であった。

治療は全例全身麻酔, 喉頭顕微手術下に行っ た。レーザー出力に関しては, 当初は $5 \sim 10 \mathrm{~W}$ で行っていたが，最近では通常 $10 \sim 20 \mathrm{~W} て ゙$ 照 射している。また当初はパルス照射を主に行っ ていたが，最近では continuous waveで，病巣 に応じて切除と蒸散とを組み合わせて治療をし ている。

照射にあたっては煙の発生がかなりみられる が，私どもは通常の喉頭鏡に 2 つ排煙用チャ ンネルを装着したものを試作使用し，良好な術 野を得ている。

\section{結果}

$\mathrm{T} 1 \mathrm{a}$ 症例の治療結果を表 2 に示す。レーザー 単独が 10 例, 放射線併用が 7 例の計 17 例で，い ずれも初回治療で $100 \%$ 腫瘍は消失しており,そ の後の再発も認めていない。レーザー手術回数 は 2 回ないし 3 回を要した症例が 3 例あった が，そのほかの14例は 1 回で治療を終了してい る。

$\mathrm{T} 1 \mathrm{~b}$ 症例の治療結果を表 3 に示す。レーザー 単独の 5 例中の 3 例は腫腸の消失をみたがうち 1 例は 4 力月後に再燃し, 最終的に 2 例がレー ザー単独で， 3 例が喉頭摘出で治瘾した。放射 線併用の 9 例は初回治療で全例腫瘍の消失をみ たが，うち 1 例は 2 年後に再燃を認め喉頭摘出 を行った。レーザー手術回数でも，2 回行った ものが 4 例で 3 回が 3 例と複数回行う必要のあ ったものが半数を占めた。
表 2 T1aの治療結果

\begin{tabular}{c|c|c|c}
\hline & 症例数 & 成功例 & 喉摘例 \\
\hline $\begin{array}{c}\text { レーザー } \\
\text { 単 独 }\end{array}$ & 10 & $\begin{array}{c}10 \\
(100 \%)\end{array}$ & $\begin{array}{c}0 \\
(0 \%)\end{array}$ \\
\hline $\begin{array}{c}\text { レーザー } \\
+ \text { 放射線 }\end{array}$ & 7 & $\begin{array}{c}7 \\
(100 \%)\end{array}$ & $\begin{array}{c}0 \\
(0 \%)\end{array}$ \\
\hline 計 & 17 & $\begin{array}{c}17 \\
(100 \%)\end{array}$ & $\begin{array}{c}0 \\
(0 \%)\end{array}$ \\
\hline
\end{tabular}

表 $3 \mathrm{~T} 1 \mathrm{~b}$ の治療結果

\begin{tabular}{c|c|c|c}
\hline & 症例数 & 成功例 & 喉摘例 \\
\hline $\begin{array}{c}\text { レーザー } \\
\text { 単 独 }\end{array}$ & 5 & $\begin{array}{c}2 \\
(40 \%)\end{array}$ & $\begin{array}{c}3 \\
(60 \%)\end{array}$ \\
\hline $\begin{array}{c}\text { レーザー } \\
\text { +放射線 }\end{array}$ & 9 & $\begin{array}{c}8 \\
(89 \%)\end{array}$ & $\begin{array}{c}1 \\
(11 \%)\end{array}$ \\
\hline 計 & 14 & $\begin{array}{c}10 \\
(71 \%)\end{array}$ & $\begin{array}{c}4 \\
(29 \%)\end{array}$ \\
\hline
\end{tabular}

表 4 T2 の治療結果

\begin{tabular}{c|c|c|c}
\hline & 症例数 & 成功例 & 喉摘例 \\
\hline $\begin{array}{c}\text { レーザー } \\
\text { 単 独 }\end{array}$ & 1 & $\begin{array}{c}0 \\
(0 \%)\end{array}$ & $\begin{array}{c}1 \\
(100 \%)\end{array}$ \\
\hline $\begin{array}{c}\text { レーザー } \\
\text { 十放射線 }\end{array}$ & 4 & $\begin{array}{c}2 \\
(50 \%)\end{array}$ & $\begin{array}{c}2 \\
(50 \%)\end{array}$ \\
\hline 計 & 5 & $\begin{array}{c}2 \\
(40 \%)\end{array}$ & $\begin{array}{c}3 \\
(60 \%)\end{array}$ \\
\hline
\end{tabular}

T 2 症例の治療結果を表 4 に示す。レーザー 単独では腫瘍は消失せず, 放射線併用で 4 例中 2 例に腫瘍の消失をみた。全体として 3 例が喉 頭摘出を要し, うち 1 例は喉摘後早期に局所再 発を認め死亡した。レーザー手術回数について は，3例は 1 回，1 例は 2 回であったが，死亡 した例には 4 回行って抢り, 早期に摘出手術に ふみきるべきであったと反省している。

症例のうちいくつかを図 $1 \sim 3$ に示す。術後 の局所所見を定期的に喉頭ファイバースコープ で観察しているが, 創傷治瘺過程において気づ いた点を列挙する。術創には術後数日で白苔が 付着し, これが脱落して上皮化が完了するのに 1〜2 カ月を要する。切除あるい潦散の範囲 が前連合を含んで両側声带にわたるものでは, web を形成するものがある。切除あるいは蒸散 

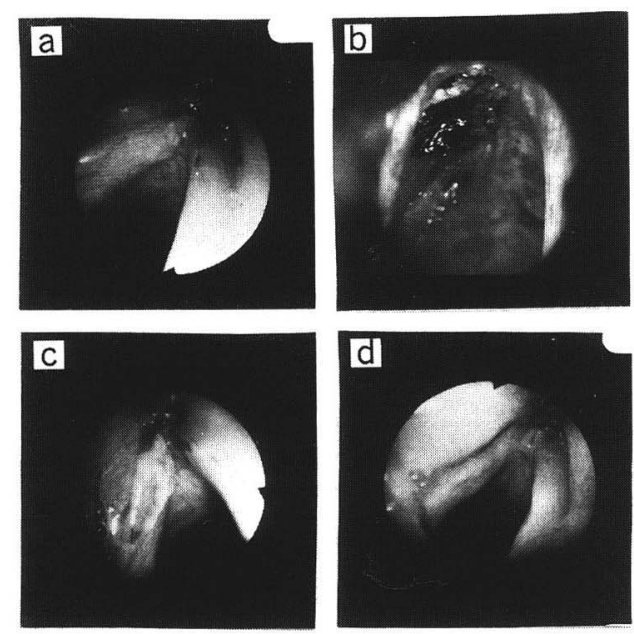

図 175 歳, 男性, T1a

$\mathrm{a}:$ 術前, b: 術中, $\mathrm{c}$ : 術後 7 日, $\mathrm{d}:$ 術後 2 年。
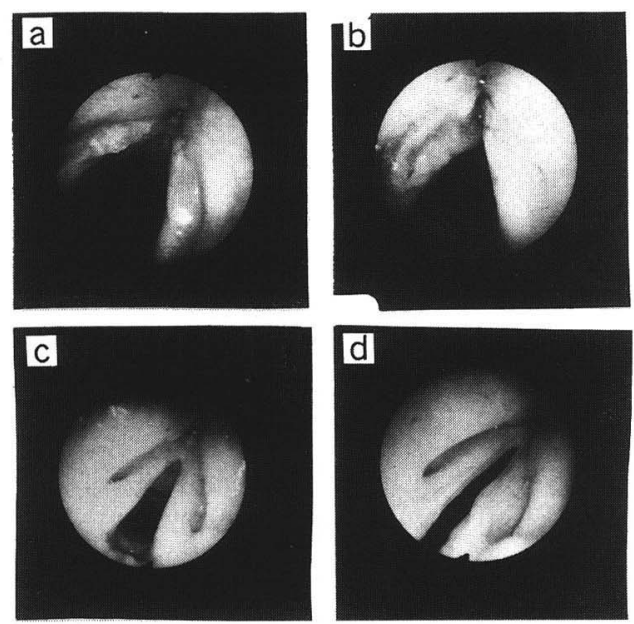

図 2 51歳, 男性, T1b

$a$ : 術前, b: 術後 8 日, $c$ : 術後 75 日, $d:$ 術後 4 年。

の深さが声帯筋に達するものでは, 治癒後の声 帯に欠損を認めるものがある。

以上をまとめると, 経過観察期間は 9 力月か ら 6 年 8 力月, 平均 3 年 2 力月で, 36 例中 35 例, 97\%は生存しており，腫崵の再発も認めていな い。また喉頭摘出を行った率は19\%（7/36）で あった。

\section{考察}

T1a 症例についてみると, 10例がレーザー単 独で治療できている。放射線併用の 7 例のうち
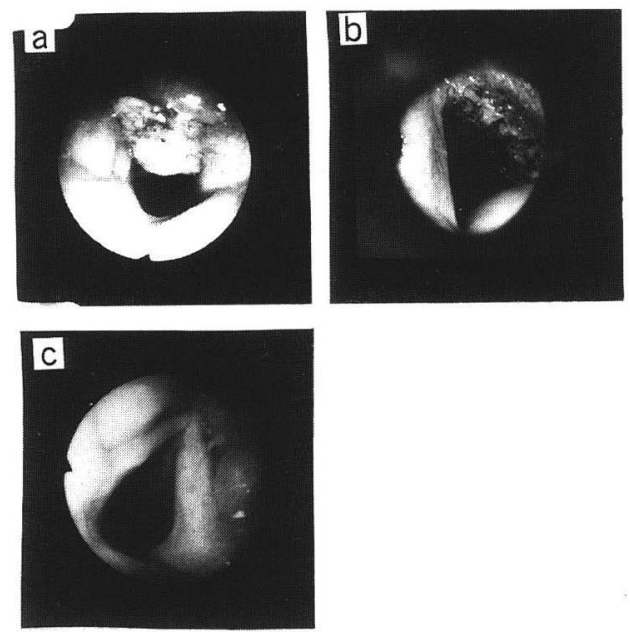

図 359 歳, 女性, T1b

$\mathrm{a}:$ 術前, $\mathrm{b}:$ 術中, $\mathrm{c}$ : 術後 2 年。

表 5 初回レーザー治療後の腫瘍残存率

\begin{tabular}{c|c|c}
\hline 部 位 & $\mathrm{N}$ & 腫瘍残存率 \\
\hline 前 連 合 & 16 & $31 \%(5 / 16)$ \\
声帯膜様部 & 42 & $31 \%(13 / 42)$ \\
声 帯 後 方 & 17 & $47 \%(8 / 17)$ \\
\hline
\end{tabular}

わけは, レーザー手術後の生検で腫瘍は認めら れなかったが念のため放射線を追加したものが 3 例, 術前照射後の残存腫瘍に対してレーザー で治療したものが 2 例，レーザー手術後の残存 腫瘍に対して放射線で治療したものが 2 例であ つた。レーザー治療後腫痬が残存していた 2 例 は, 当科においてレーザー治療を開始した当初 の症例であり, 病巣の範囲を詳細に確認し十分 な切除を行っていれば腫瘍を消失せしめえたも のと思われる。以上を総括すると, $\mathrm{T} 1 \mathrm{a}$ 症例は レーザー治療単独で根治できると考える。

T1b 症例では, 放射線を併用したものが 9 例 あり，このうちわけは，レーザー手術で腫瘍は 消失したが念のため放射線を併用したものが 3 例, 術前照射後の残存腫瘍に対してレーザーで 治療したものが 3 例, レーザー治療後の残存腫 瘍に対して放射線で治療したものが 3 例であっ た。このうち 1 例は 2 年後に再燃を認め喉頭摘 出を行った。またレーザー単独の 5 例中 2 例は レーザー後に残存腫瘍を認め, 1 例は後に再燃 し, 計 3 例に喉頭摘出を行っている。以上を総 
括すると, T1b 症例ではレーザー単独で治療で きるものもあるが，放射線の併用を要したもの が多かった。この理由としては, 術後の音声を 考慮して両側声帯の広範囲な切除が行われなか ったこと, 病巣が声帯後方や喉頭室方向に進展 しているものが多く，切除が困難なものがあっ たことなどが考えられる。

そこで T1a，T1b 症例について，1回目のレ ーザー治療で腫瘍を取り切れなかった率を部位 別に検討したところ, 前連合や膜様部といった 術野のとりやすい所に比べて，㨂管チューブが 邪魔になる後方では腫瘍残存率が高かった（表 5 )。治瘠率の向上をはかるために, 現在ではレ ーザー治療の手術手技のこつとして，以下のよ うな点に注意して行っている3 。

すなわち，声帯後方の病巣に対しては插管于 ユーブを喉頭鏡で前方に置き換え術野をとる。 喉頭室方向の十分な切除が必要なものでは，あ らかじめ仮声带を切除しておいてから腫瘍を切 除する。切除あるいは蒸散の深さについては, 明らかに表層のもの以外では, 膜様部では声帯 靱帯あるいは声帯筋のレベルまで，前連合では 甲状軟骨を露出するまで行う。

以上のほかにも，気管切開を置きここから挿 管してチューブを術野からはずすこと，喉頭鏡 を改良してより広い術野を得ることなども考慮 中である。

T 2 症例では， 5 例中 2 例が放射線併用で治 療できているが，これらはいずれも術前照射後 の残存腫瘍に対してレーザー治療を行ったもの であった。症例数が少ないため十分な検討はで きていないが, T 2 症例ではレーザー治療の適 応となるものは限られ, 慎重な症例の選択が必 要となる。

術後の音声に関しては，詳細な検討を行って
いないが，他の報告 ${ }^{4)}$ と同様に私どもの経験で も放射線治療と比べて多少劣る印象はあるもの の，高度の障害を生ずるものは少ないようであ る。ただし，両側声帯に広範な腫瘍を認め，広 範囲に深く切除を要するような $\mathrm{T} 1 \mathrm{~b}$ 症例で は，両側声帯の欠損のため高度の気息性嗄声を 生じたり, web 形成のための音声障害を認める ものがあった。また，前連合を深く切除したも のにも web 形成がみられることがあった。

\section{ま と め}

声門部喉頭癌新鮮例36例に対して $\mathrm{CO}_{2} レ ー$ ザー治療を行い検討を加えた結果，その適応に ついて以下の結論を得た。

1. 声門癌 T1a 症例はレーザー治療単独で 根治しうる。

2. 声門癌 $\mathrm{T} 1 \mathrm{a}$ 症例のうち腫瘍が声帯突起 をこえて後方に進展しているものは，放射線治 療の併用を要することがある。

3．声門癌 $\mathrm{T} 1 \mathrm{~b}$ 症例はレーザー治療単独ま たは放射線併用で根治しうるが，両側声帯の広 範な切除を要するものは術後の音声に問題を残 す。

4. 声門癌 $\mathrm{T} 2$ 症例のレーザー治療には症例 の選択が必要である。

\section{文献}

1) Inouye, T.: Clinical application of $\mathrm{CO}_{2}$ LASER to head and neck surgery. New Frontiers in Laser Medicine and Surgery, pp.251259, Excerpta Medica, Amsterdam, 1982.

2 ) 井上鐵三：喉頭腫瘍に対するレーザーの応用. 日本レーザー医学会誌，5：513-515, 1985.

3 ) 田部哲也：喉頭癌レーザー治療における再発例 の検討。日本レーザー医学会誌，8：267-268, 1987.

4 ）上垣克己：声帯に対するレーザー手術後の発声 機能.耳鼻と臨床，34：525-546, 1988. 